Large-scale agricultural investments trigger direct and indirect land use change: New evidence from the Nacala corridor, Mozambique

Julie G. Zaehringer ${ }^{\mathrm{a}, *}$, Ali Atumane ${ }^{\mathrm{b}}$, Sibylle Berger ${ }^{\mathrm{a}}$ and Sandra Eckert ${ }^{\mathrm{a}}$

a Centre for Development and Environment, University of Bern, Hallerstrasse 10, 3012

Bern, Switzerland; julie.zaehringer@cde.unibe.ch, sandra.eckert@cde.unibe.ch

b Faculty of Agriculture, Catholic University of Cuamba, Cuamba, Mozambique;

aatumane@ucm.ac.mz

* $\quad$ Correspondence: julie.zaehringer@cde.unibe.ch; Tel.: +41-31-631-88-69; ORCiD:

0000-0002-3253-5128; Twitter: @julie_gwen 


\title{
Large-scale agricultural investments trigger direct and indirect land use change: New evidence from the Nacala corridor, Mozambique
}

\begin{abstract}
The Nacala corridor in Mozambique is one of the main host regions for large-scale agricultural investments (LAIs) in Africa. LAI companies produce crops for export, with scarcely known impacts on small-scale farmers and the environment. We conducted 101 interviews with smallscale farmers living near an LAI to elicit their perceptions of the LAI's impacts on their own land use and the environment. Additionally, we used remote sensing to assess land use change between 2000 and 2015 in two study areas in Guruè and Monapo districts. The results show that LAIs caused deforestation both directly and indirectly. The main environmental impact perceived by farmers was that LAIs had blocked their access to rivers. Positive spillovers did occur, but could not compensate for the negative impacts experienced. A peaceful coexistence of LAIs and smallscale farmers in the Nacala corridor is only possible if existing injustices around the occupation of land are resolved.
\end{abstract}

Keywords: Nacala corridor; indirect land use change; displacement; deforestation; large-scale agricultural investments; spillovers

Word Count: 7,531 


\section{Introduction}

The 2008 food price crisis drew investors' attention to what was widely perceived as a vast resource of “idle” or “underused” land in Africa (The World Bank, 2011). Today, large-scale agricultural investments cover about 10 million hectares of African farmland (Nolte, Chamberlain, \& Giger, 2016). In theory, such investments can benefit host countries by improving their overall agricultural production, and local populations by alleviating poverty (Collier \& Dercon, 2014; Smaller, Speller, Mirza, Bernasconi-Osterwalder, \& Dixie, 2015). In reality, however, few of them have held these promises (Breu et al., 2016; White, Jr, Hall, Scoones, \& Wolford, 2012).

Mozambique is one of the main host countries for international agricultural investments in Africa (Nolte et al., 2016). After independence from Portugal in 1975, the country adopted a socialist development ideology, promoting collectivization as well as state-owned farms to foster development of the agricultural sector. The failure of this model was an important factor contributing to the outbreak of a civil war lasting from 1977 to 1992 . The war inflicted massive losses on the cash crop sector, forcing many farmers back into subsistence agriculture, and destroyed much of cattle production as well as basic infrastructure. Towards the end of the war, Mozambique joined the structural adjustment programmes of the International Monetary Fund and the World Bank (Hofmann, 2013). With the transition towards a liberalized market economy, the country, and especially the agricultural sector, became highly dependent on aid (Cabral, 2009; De Renzio \& Hanlon, 2007). Reforms of the agricultural sector were supported by the European Union (EU), the World Bank, the United Nations Food and Agriculture Organization (FAO), the United Nations Development Programme (UNDP), and the Danish International Development Agency (DANIDA). Nevertheless, the country still faces a deficit in food production and strongly relies on imports (Amanor \& Chichava, 2016). Despite policy frameworks aimed at strengthening family farming, the emphasis has clearly shifted towards 
seeking foreign investments into large-scale agriculture. The government attracts investors by enabling them to acquire secure land use and benefit rights, known as Direito de Uso $e$ Aproveitamento da Terra (DUAT) (German, Cavane, Sitoe, \& Braga, 2016). Under the New Alliance for Food Security and Nutrition of the G8, which was proposed by the government of the United States and signed by many states and multilateral institutions, a Framework Agreement was signed with Mozambique. At the national level, this subsequently translated into national public policy favouring agricultural investments (UNAC \& GRAIN, 2015). Emerging growth corridors like the Nacala corridor (Di Matteo \& Schoneveld, 2016) are part of the government's Strategic Plan for the Development of the Agricultural Sector 2011-2020 (PEDSA) (Republica de Moçambique, Ministério da Agricultura, 2011) as well as the National Investment Plan for the Agricultural Sector 2013-2017 (PNISA) (Republica de Moçambique, Ministério da Agricultura, 2013). The Nacala corridor is one of four planned corridors within the African Agricultural Growth Corridor initiative announced at the World Economic Forum in 2009 (Ikegami, 2015). Its prestige project ProSAVANA, backed by Japanese and Brazilian investors, was considerably slowed down after Brazilian investors realized that most land was actually farmed by small-scale farmers and that land rights were rather strong (Wise, 2014); and also due to widespread protests by a coalition of Mozambican and international NGOs (Shankland \& Gonçalves, 2016). However, in 2016, the project's implementing bodies released the draft of their master plan (Cooperação Triangular para o Desenvolvimento Agrário da Savana Tropical em Moçambique, 2016), and according to the most recent news, ProSAVANA activities are underway despite continued strong opposition (No to ProSavana Campaign, 2018). Overall, between 2002 and 2013, almost 500 agricultural investments were approved in Mozambique; of these, 30\% were operational in 2013 (Di Matteo \& Schoneveld, 2016). Many of these projects have led to the displacement of farmers - despite the new land law, which grants local people the right to any land they have been farming for more than 10 years. In several cases, investors met with strong resistance from farmers and civil rights organizations 
(Norfolk \& Hanlon, 2012; UNAC \& GRAIN, 2015). Displacement of land users seems to be a very common phenomenon, despite the fact that Mozambique is recognized as having one of the most progressive land laws in Africa, which in the absence of formal titling treats customary land rights with the same respect as it does other land rights (German et al., 2016).

The land that investors target in Mozambique is mostly covered by mosaics of forest, shrubland, and farmland (Di Matteo \& Schoneveld, 2016). The establishment of large-scale farms usually involves the clearing of land and, accordingly, the loss of important ecosystem services and biodiversity. In addition, indirect land use changes (or "leakage effects”) occur when land uses displaced from a given location are reallocated to another location (Bergtold, Caldas, Sant'anna, Granco, \& Rickenbrode, 2017; Lambin \& Meyfroidt, 2011). The concept of indirect land use change has been proposed to address the unintended release of greenhouse gas emissions triggered by the expansion of cropland for biofuel production (Finkbeiner, 2014; Searchinger et al., 2008). This is happening in the Brazilian Cerrado region, where the production of sugarcane ethanol on existing pasture or cropland has led to the intensification of food and feed crops on pasture and cropland and to the expansion of cropland at the expense of tree cover in frontier areas (Barretto, Berndes, Sparovek, \& Wirsenius, 2013). Apart from increasing greenhouse gas emissions, indirect land use change can have various other impacts, such as reduced biodiversity and altered microclimates, among others. Indirect land use change often occurs at the global or regional scale, far from the originally displaced land use (e.g. Andrade de Sá, Palmer, \& di Falco, 2013), but it may also occur locally. Bergtold et al. (2017) found that farmers surveyed in the Brazilian Cerrado had converted pastureland to soybean production after this land use had been displaced by sugarcane expansion.

The existing literature on indirect land use change focuses almost exclusively on biofuel production in South America. Although the African continent has attracted countless large-scale agricultural investments (LAIs) for production of a wide range of crops, only few studies so far look at the indirect land use change caused by LAIs in Africa. Exceptions include one study on 
a large-scale jatropha plantation in Mozambique, which found small-scale farmers clearing miombo woodlands for crop cultivation (von Maltitz, Gasparatos, Fabricius, Morris, \& Willis, 2016). Case studies of jatropha in Ghana showed that small-scale farmers who had lost land to jatropha companies were forced to shorten their fallow periods, with negative consequences in terms of soil degradation (Acheampong \& Campion, 2014; Schoneveld, German, \& Nutakor, 2011). In Zambia, German et al. (2011) observed indirect land use change in the context of jatropha introduction on small-scale farmers' land, to which farmers had responded by clearing forest areas to cultivate their displaced food crops.

The fact that Mozambique ranks 181st of 188 countries in terms of its Human Development Index (UNDP, 2016) highlights the need for LAIs in this country to provide co-benefits for local populations or, at the very least, to not further jeopardize their well-being. But despite the large number of investments in Mozambique, little empirical evidence has been published on the impacts these LAIs have on poverty alleviation, and even less on how they affect land use and the environment (Rulli \& D’Odorico, 2017). Deininger and Xia (2016) analysed data from the agricultural census which suggest that there were some positive spillover effects from LAIs onto neighbouring small-scale farms, for example in terms of access to inputs and employment. A study on households' perception of a large-scale jatropha plantation in Sofala province found only few negative impacts of the LAI on ecosystem services and small economic benefits (von Maltitz et al., 2016). Joala et al. (2016) reported that people living near a LAI producing macadamia in Guruè district had lost access to streams and other natural resources. These scarce and diverging findings suggest that we need more comprehensive studies of LAI impacts on land use and the environment to fully grasp their implications for sustainable development.

LAIs are a prominent example of how land, especially in developing countries, is being revalorized based on increasing global demand for food and fuel crops (Nolte et al., 2016; Verburg et al., 2015). Our study is embedded in land system science, whose aim is to better understand the causes of such phenomena along with their consequences in terms of land use 
change (Reenberg, 2009; Turner, Lambin, \& Reenberg, 2007). Achieving this aim requires increased differentiation between causal effects and causal mechanisms. (Meyfroidt, 2015). While remote sensing is an important means of monitoring and assessing land use and land cover (LULC) changes (Ariti, van Vliet, \& Verburg, 2015; Lambin \& Geist, 2008; Rogan \& Chen, 2004; Scharsich, Mtata, Hauhs, Lange, \& Bogner, 2017; Wulder et al., 2008; Zhu \& Woodcock, 2014), establishing causal links between observed LULC changes and LAIs is difficult without more in-depth information. In this study, we therefore combined remotely sensed data with the perceptions of small-scale farmers voiced in interviews to confirm the causal link between selected LULC changes in the Nacala corridor and the presence of LAIs. We specifically aimed to answer the following research questions: (1) To what degree are smallscale farmers involved with the LAIs in their vicinity, and are there positive spillovers in terms of knowledge and technology transfer? (2) How has land use in the surroundings of LAIs changed over the past 20 years? (3) How has small-scale farmers' land use changed, and is there

any evidence of indirect land use change caused by LAIs? (4) What are the overall impacts of LAIs on the environment and social-ecological systems as perceived by small-scale farmers? To answer these questions, we analysed data from interviews with 101 small-scale farmers living near selected LAIs in the Nacala corridor and related those findings to LULC change information from remotely sensed data.

\section{Methods}

\section{Study Areas}

We selected two study areas in the Nacala corridor: the districts of Monapo in the east and Guruè in the west (Figure 1). They represent two different agroecological zones and thus contain different types of LAIs. Together, they cover most types of agricultural investments present in the Nacala corridor. 
Guruè district in the north of Zambézia province has about 400,000 inhabitants (Joala et al., 2016). It has a temperate climate and receives 1,400 to $2,000 \mathrm{~mm}$ of rainfall between October and April (Manhique \& Zucule, 2012), which is more than other parts of the province get. The mountainous areas have been used for tea plantations - the largest in Mozambique - since colonial times. The area has attracted different types of agricultural investors since around 2003 (Joala et al., 2016). Local production systems have changed tremendously since nongovernmental organizations (NGOs) and aid agencies began to promote soybeans in Guruè district (Di Matteo, Otsuki, \& Schoneveld, 2016). Today, soybeans are by far the main cash crop grown by small-scale farmers in the district (Joala et al., 2016).

Monapo district in Nampula province had about 351,012 inhabitants in 2012 and a population density of 99 inhabitants per square kilometre, which is about three times as high as in Guruè (INE, 2012). The district has a semiarid to subhumid climate, with annual rainfall ranging between 800 and 1,000 mm. The main rainy season occurs from January to March (Manhique \& Zucule, 2012). Small-scale rainfed cultivation of maize and pulses is the main economic activity in both districts.

During fieldwork in 2016 we identified 12 companies involved in LAIs in Guruè district, of which 10 were at least partly owned by foreign investors. We selected three of the latter for closer investigation in the present study (Table 1, LAI1-LAI3). All three had been established between 2009 and 2012. In Monapo we found 13 companies active in LAIs, of which five were at least partly owned by foreigners. Here, too, we selected three companies for closer investigation that had been established between 2007 and 2013 and were at least partly foreignowned (Table 1, LAI4-LAI6). The selected LAIs are representative of the most recent wave of LAIs in the Nacala corridor. In terms of market destinations of the selected LAIs' produce, soybeans were purchased by large poultry companies based in Nampula and Manica provinces, while macadamia nuts were exported mainly to South Africa. Bananas were exported to Eastern Europe, the Middle East, South Africa, Zimbabwe, and Zambia. Vegetables were produced for 
local markets in Nampula and Pemba. It should be noted that LAI4 went bankrupt in March 2018 due to the Panama disease affecting its banana plants in what is the first reported incidence of the disease in Mozambique (Hanlon, 2018).

\section{Interviews with small-scale farmers}

We interviewed a total of 101 small-scale farmers living within one (Guruè) to two (Monapo) kilometres from one of the six LAIs. The interviews took place between October and December 2016. To select households, we created 20 random points within a one- or two-kilometre buffer around each LAI in ArcGIS. In the field, enumerators asked the household closest to the coordinates of a random point for permission to conduct an interview. If the household refused, they continued to the next closest household. Between 13 and 20 small-scale farmers were interviewed around each LAI. Interviews were held with the household member who declared him- or herself to be most familiar with the household's current land use activities. Overall, 85 respondents were men and 16 women. The interview guide contained open and closed questions on three main topics: (1) general household characteristics and involvement with the LAI; (2) perceived land use and crop management changes and their link to the LAI; (3) perceived direct impacts of the LAI on the environment and on the household in general. Three local enumerators conducted the interviews in Makua or in Portuguese and took notes in Portuguese as well as audio recordings. The interview transcripts were later translated into English. Interviews lasted around 1 hour. Qualitative information was coded by the main author and transferred to an Excel database for statistical analysis. We calculated frequencies of responses using the R statistical software (R Core Team, 2015). As the three LAIs in Monapo district were located very close to each other, we decided to treat them as one case for analysis of the interview data. Accordingly, we compared a total of four cases in the analysis. 


\section{Processing and analysis of remotely sensed data}

To verify and support small-scale farmers’ perceptions regarding LULC changes in their area and how they are linked to the establishment of the analysed LAIs, we classified the study areas' LULC at two distinct times based on remotely sensed data and did a spatially explicit LULC change analysis for the period in between. The intention was not to establish causal links between the LAIs and general LULC change in the study areas - which is not possible based on such a change analysis - but to investigate the direct impacts of LAIs on LULC and to identify overall LULC trends in the study areas in order to put respondents’ perceptions into a broader context.

We performed the classifications and change analysis using the Google Earth Engine cloud computing environment. We queried the United States Geological Service (USGS) Landsat data archive for Landsat Ecosystem Disturbance Adaptive Processing System (LEDAPS) surface reflectance products, which are already geometrically coregistered, orthorectified, and atmospherically corrected. The products are provided with a cloud mask and a quality assessment band. For each selected product we additionally calculated the Normalized Difference Vegetation Index (NDVI).

We generated two image collections representing the situation in 2000 and in 2015. In order to obtain cloud-free seasonal composites of surface reflectance we had to include two to four years of imagery for each point in time. For 2000, we used imagery acquired between 1999 and 2002; for 2015, we used data acquired between 2014 and 2016 for Guruè and between 2015 and 2016 for Monapo. This resulted in two raster data stacks representing the two study areas in the dry season, in the wet season, and in between. Such seasonal composites representing key phenological time windows can be helpful in separating certain land cover and land use classes in a reliable way (Griffiths et al., 2014; Griffiths, Müller, Kuemmerle, \& Hostert, 2013). A more detailed description of the method used to generate these seasonal image collections is available 
in (Eckert, Kiteme, Njuguna, \& Zaehringer, 2017). We chose the year 2000 as the baseline situation for the LULC change analysis because gap-free and monthly data for years more immediately preceding LAI establishment were not available due to a technical failure of the Landsat ETM+ sensor between 2002 and 2014. Nevertheless, we created dry-season composites for 2005-2007 and did a careful visual check to make sure that no major LULC changes had occurred before the implementation of the LAIs - whose pilot phases in some cases began as early as 2008. However, due to the reduced quality (data gaps and banding) of these 2005-2007 composites, we could not use them for the analysis of LULC change across the entire study areas.

The field reference data required to train and validate the two LULC classifications were collected during a field visit in September 2016. Additional reference data were digitized in Google Earth, which offered high-resolution data captured in 2003, 2005, and 2016 for areas in Monapo and 2006, 2015, 2016, and 2017 for areas in Guruè.

We defined LULC classes that reflect the natural vegetation cover in the two study areas, as well as ones that reflect land covers and uses that developed with increasing human activities in the study areas. All raster data stacks were classified using random forest (RF), an ensemble method for supervised classification, and regression trees (CART), developed by Breiman (2001). RF is a high-performance machine learning algorithm based on an ensemble of decision trees. We used 1,000 trees for the RF model, and the number of selected features was set as the square root of all features. The Gini coefficient served as the impurity criterion. The accuracy of the resulting LULC classifications was assessed using a 10-fold cross-validation procedure and withholding $10 \%$ of our field reference data to independently assess the accuracy of the RF model. We calculated overall accuracy, class-wise user’s and producer's accuracies, as well as kappa accuracy (Congalton \& Green, 2008). The overall accuracies for 2000 and 2015 range between $87 \%$ and 92\%. The kappa accuracies lie between $83 \%$ and $90 \%$. Detailed class accuracies for the two subsets of Monapo and Guruè are provided in Tables S1 and S2 in the 
Supplementary Material. We assessed LULC change for each pixel by creating cross-tabulation matrices for the interval from 2000 to 2015 and calculating net change within a $5 \mathrm{~km}$ buffer around each LAI.

\section{Results and Discussion}

\section{Involvement of interviewed households with LAIs}

Almost half (45\%) of the households interviewed $(\mathrm{n}=101)$ had lived at the current location since the respondent's birth (Table 2). Only 9\% of those respondents who had not been born in the area $(n=56)$ had moved there because they had found employment with one of the LAI companies; however, another $16 \%$ had moved there to look for work. This shows that the prospects of potential employment with an LAI company have attracted a certain number of immigrants to the Nacala corridor. All but one of the households interviewed depend on subsistence farming $(99 \%, \mathrm{n}=101)$, and a large majority commercialize part of their crops, selling them mainly on local markets (87\%). On average, households cultivate less than three hectares of cropland. At the time of the interviews, $22 \%$ of all households ( $n=101)$ had at least one member working for one of the LAI companies, which shows that LAIs are a further important source of income in the study areas. This is in line with the findings of Deininger and Xia (2016), whose analysis of nationwide agricultural survey data confirms that the establishment of LAIs led to job creation for small-scale farmers within a radius of 25 kilometres. Furthermore, in another $24 \%$ of households one or more household members had worked for an LAI company in the past but had stopped doing so. This suggests that the LAI companies in our study areas have a high fluctuation of workers. Overall, more than half (55\%) of the households interviewed ( $\mathrm{n}=101)$ had never had a household member employed by an LAI company. The main reason stated by respondents was the difficulty of finding a job (49\%, $\mathrm{n}=55$ ) - especially in Monapo. This indicates a high demand for wage labour from small-scale 
farmers in the Nacala corridor. However, another $22 \%$ of those who had never been employed by an LAI company had been discouraged by the perceived bad working conditions, which included companies firing workers for no reason, and the poor salaries paid. Only 9\% preferred to work on their own farm, mainly around LAI1, and a few respondents generally had no interest in employment with an LAI company (6\%). Among the households with one or more members currently or previously employed by an LAI company ( $n=46), 59 \%$ stated that this did not affect labour availability for their own farming activities, while 15\% said it meant that they no longer had enough labour available. One respondent said that the income from their employment with the LAI company had enabled them to hire someone to work their own fields. Further, among the households with a member currently or previously employed by an LAI company ( $n=46)$, 33\% said that they had learned something while working for the LAI company that they found useful for their own farm. The topics mentioned most frequently in this context were horticultural techniques, use of chemicals, use of fertilizers, mechanized farming, and irrigation techniques. These results indicate that positive spillovers in terms of agricultural technology transfer seem to occur at least for some farmers employed with an LAI company.

\section{Impacts of LAIs on LULC changes}

In this section, we present small-scale farmers' perceptions of LULC changes related to their own land use activities and of tree cover changes in the surrounding landscapes. We relate these perceptions to the results of our remote sensing analysis, in which we focused on both the land of the newly established LAIs and their surroundings. While the remote sensing analysis does not enable us to establish causal links between the LAIs and LULC changes in general, it does shed light on the LAIs' direct impacts on LULC and supports respondents' claims that the LAIs were at least partly established on previously cultivated cropland and thus contributed to deforestation in the area. Furthermore, it enables us to put respondents' statements about local- 
level changes linked to their own land use activities into the context of overall LULC trends in the study areas.

In our description of results, we refer to "households losing land to an LAI" and "an LAI taking land from local households”. We have chosen this wording despite the contractual agreements existing between the LAI companies and the government. As German et al. (2016) have shown, non-compliance with agreed conditions of land alienation and with partnership agreements is widespread in Mozambique, and none of the farmers we interviewed in the Nacala corridor had participated in land negotiations or formally agreed to giving up their land. In their view, the situation was such that they had no other choice but to cede their land to the investors.

Changes in cropland: Overall, more than $60 \%$ of the households interviewed had changed the size of their cropland since they had started to cultivate it (Table 3). In almost all LAI cases analysed, more households reported a decrease in cropland than an increase. However, results from the remote sensing analysis show an overall net increase in small-scale farmers' cropland between 2000 and 2015 of almost 5\% of the total analysed area in Guruè and Monapo (Table 4). This contradiction can be explained by the fact that our survey focused specifically on households close to the selected LAIs, which are much more likely to have lost land to an LAI than households located further away. The remote sensing results, on the other hand, show an overall trend of cropland expansion in the wider landscape as it is common in most rural areas of Sub-Saharan Africa, where small-scale farmers, in the absence of agricultural inputs, are trying to increase production and adapt to increasing soil degradation by expanding their cropland (IAASTD, 2009). Indeed, a study on cropland expansion across the tropics showed that Mozambique ranked 17th of 128 countries in terms of its annual increment in cropland between 1999 and 2008, which averaged $724 \mathrm{~km}^{2}$ and resulted almost entirely from the expansion of annual crops (Phalan et al., 2013). The main reason stated by those respondents who had expanded their cropland was that they had wanted to increase their overall crop 
production; only two respondents near LAI1 said they had had to expand their cropland in order to be able to leave part of the land fallow (Table 3). Two thirds of the households who had expanded their cropland had done so at the expense of forest, whereas the remaining third used existing crop- or bushland (Table 3). This shows that cropland expansion by small-scale farmers remains an important direct cause of deforestation in our study areas.

More than $90 \%$ of those households who had experienced a net decrease in cropland $(n=47)$ stated that this was because their land had been taken by the nearby LAI. This means that the land was still used for crop production but was now farmed by one of the LAI companies instead of small-scale farmers. Only one of the respondents who reported a decrease in cropland had passed cropland on to his son, who had converted it into a cashew plantation (Table 3).

Land use displacement: Overall, about half of all interviewed households had lost land to one of the LAIs. Their proportion was particularly high around LAI2 and LAI3 in the Guruè study area, where around three quarters of the interviewed households were affected. Households had lost more than 3 ha on average across all cases, and one household had lost as much as 25 ha to one of the soy-producing LAIs in the Guruè study area (Table 3). Eight of those households who reported no change or an overall increase in cropland had also lost cropland to one of the LAIs but had been able to replace it with an equivalent or even larger area of land elsewhere. The remote sensing analysis confirmed these statements, showing that the analysed LAIs occupied 3,917 hectares of what had previously been small-scale cropland. This corresponds to 55\% of the LAIs' total surface (Table 5). Especially LAI2 in Guruè and LAI4, LAI5, and LAI6 in Monapo were almost entirely established on previous small-scale farmers' cropland. The establishment of LAI2 had involved the conversion of almost 2,000 hectares of small-scale cropland - fertile land that had used to be a cereal plantation in colonial times - into soya plantations, which corresponds to 85\% of the LAI’s surface (Figure 2, Table 5). This illustrates Mozambique’s complex land use history after the country's independence, when Portuguese 
colonial estates were turned into state farms. Due to mismanagement and insecurity during the civil war, many of them collapsed and were gradually occupied by small-scale farmers (often former state farm workers). Many of these farmers were legally entitled to the land, as they had occupied it in good faith for more than 10 years; but with the arrival of the investors, who had applied for and had been granted a DUAT by the government, the farmers were nonetheless expelled from the land (Cabral \& Norfolk, 2016). In Monapo, the increase in monoculture banana plantations - belonging to LAI4, which became operational in 2007 - constituted the largest positive net change (1,437 ha) in all analysed LULC classes in that case study area (Table 4). As much as $80 \%$ of the three analysed LAIs in Monapo were established on previous small-scale farmers' cropland (Figure 3, Table 5). This indicates that although only about 40\% of interviewed households in Monapo reported having lost land to one of the LAIs, it is likely that many more households shared the same experience. While small-scale cropland was the largest overall source of land for the LAIs in our study, another 39\% of their area had previously been forest and bushland (2,797 ha), and the remaining 6\% had mainly been natural wetlands (454 ha). Particularly LAI1 and LAI3 were to a large extent established on previously forested land. Nevertheless, the establishment of LAI1 had involved the conversion of 301 hectares of small-scale cropland into soya plantations, while LAI3 had converted 271 hectares of smallscale cropland into macadamia plantations and mechanically irrigated crop farming (Figure 2). In sum, the results from our LULC change analysis show that in all four cases analysed, the LAIs had partly been established on land previously cultivated by small-scale farmers. This refutes the assumption made by government and development actors that LAIs bring idle land into production (Deininger \& Byerlee, 2011). In fact, as we will see in the following paragraphs, it is the small-scale farmers who lost their land to LAIs who have had to search for new, socalled "idle" land and make it arable. 
In theory, the Territorial Planning Law (Law 19/2007) provides for the payment of "just compensation” for the loss of standing crops or trees (Cabral \& Norfolk, 2016). However, our results show that not even half of the households who had lost land to one of the LAIs had received any kind of compensation. This depended highly on the specific LAI company involved. In the cases of LAI1 and LAI2, all households had received some small compensation; according to respondents near LAI1, it had been calculated based on the number of trees on their land. Only two respondents near LAI3, and only one respondent near the three LAIs in Monapo had received anything in exchange for their cropland. Nevertheless, more than $60 \%$ of those households who had lost land to one of the LAIs had managed to acquire new cropland (Table 3). However, households who had lost land to an LAI still ended up with an average $1.8( \pm 3.4)$ ha less cropland than before $(n=48)$. Overall, $75 \%$ of households who had lost land to an LAI had experienced a net reduction in cropland.

A little more than $60 \%$ of those households who had acquired new cropland after having lost land to an LAI had established this new cropland in forest, clearing $3( \pm 2)$ ha of trees on average ( $n=17)$. The remaining households used existing crop- or bushland. In the case of LAI3, an important part of indirect land use change occurred on a forest patch directly adjacent to the LAI’s southern boundary (Figure 2). During a field visit in September 2016, small-scale farmers who had been displaced from their land by LAI3 showed us this patch. It consisted of miombo woodland that these farmers were now clearing in order to establish new cropland (Figure 4). This is in line with the remote sensing analysis, which showed that $91 \%$ of all new small-scale cropland in the study areas was established at the expense of forest (Table 5). The findings from the interviews indicate that part of this deforestation can be attributed to the LAIs, whose establishment displaced small-scale farmers, leaving them with little other choice than to clear new land in forested areas. LAI implementation thus contributed to an existing substantial trend of small-scale farmers expanding their cropland at the expense of forest. In other words, by occupying small-scale farmers' cropland, the LAIs further heightened the already considerable 
pressure from agricultural production on the region's natural ecosystems, thereby likely reducing important ecosystem services. In addition, some of the LAIs we examined also contributed to deforestation directly, by converting previously forested lands into monoculture plantations. Deforestation of miombo woodlands as a consequence of land use displacement has also been reported in the case of a large-scale jatropha farm in Sofala province (von Maltitz et al., 2016), but our study is one of few that confirm such processes of indirect deforestation outside the biofuel sector and for several LAIs.

When asked about the difference between their new cropland and the cropland they had lost to the LAI, most households in all four cases reported that the newly acquired cropland had a lower soil quality than the land they had lost. Two households near LAI2 said that their new cropland was located in a depression and therefore risked being flooded during the rainy season. Another household mentioned that the new land was full of tree trunks, which made it difficult to prepare the soil. One household near the Monapo LAIs said that the new cropland was further away from the river and hence the source of irrigation water. This means that these farmers had not only had to invest labour into clearing new cropland, but likely now also faced lower production due to inferior land quality. Schoneveld et al. (2011) reported a similar finding for land users in Ghana who had lost their land to a foreign biofuel company. Nevertheless, it should also be noted that two of our respondents perceived their new land to be of better quality than the land they had lost.

Changes in forest and tree cover: Three quarters of all households interviewed perceived a decrease in the landscape's tree cover (Table 3). It is worth noting, however, that $18 \%$ of these respondents ( $\mathrm{n}=77$ ) referred to timber or fruit tree plantations (mainly mango trees) rather than natural forest. The remaining respondents did not perceive any change in tree cover, with the exception of one respondent in the Monapo study area, who said the tree cover had increased. Most households stated that the decrease was due to cropland expansion; few said it was due to 
people cutting down trees for construction and other uses, or generally to population growth. However, about $12 \%$ of the respondents in Monapo said that the LAI companies had cut down trees, and one household near LAI2 mentioned that the LAI company had cut trees for construction. It appears that respondents around LAI1 and LAI3 were hardly aware that these LAIs had been established almost exclusively on previously forested land, as shown by our remote sensing analysis. Overall, the remote sensing analysis revealed that between 2000 and 2015 more than 14,000 ha of forest and bushland (8.43\% of the overall study area in Guruè and Monapo) were lost within and outside the analysed LAIs (Table 4). Only a little more than half of the respondents perceived that there was actually still some natural tree cover left in the landscape (Table 3).

\section{Perceived direct impacts of LAIs on the environment and on households}

In this section, we examine the overall perceived impacts of the LAIs on the environment and on households. For the majority of households interviewed $(60 \%, n=100)$ the LAIs had had exclusively negative impacts. Only $12 \%$ of respondents $(n=100)$ stated that the LAI in their vicinity had had exclusively positive impacts on households. Another 15\% reported positive and negative impacts, while 13\% had experienced no impacts at all. Perceptions differed widely between the six LAIs. While 71\% $(n=52)$ of respondents in Monapo perceived the three LAIs there to have had negative impacts, $43 \%$ of households near the soya-producing LAI1 in Guruè ( $n=14$ ) perceived positive impacts and 29\% perceived no impacts at all (Figure 5).

The two main positive impacts, each mentioned by $8 \%$ of respondents $(n=100)$, were an increase in employment opportunities and improved infrastructure. Around LAI1, other important positive impacts included the fact that the LAI sells crops to the surrounding communities $(14 \%, n=14)$ and that it provides amenities $(7 \%, n=14)$ or medicine $(7 \%, n=14)$ to workers. The main negative impacts of LAIs were that they had occupied farmers' land (36\%, 
$\mathrm{n}=100)$, that they mistreated workers (17\%), and that they blocked people's footpaths (16\%) or access to rivers (11\%) and forests (7\%). None of these negative impacts applied around LAI1, and the mistreatment of workers was only an issue around the three LAIs in Monapo.

The main reason for the negative perception of LAIs is that they were largely established on small-scale farmers' land. Many land users had started to cultivate new land when they settled back in the area after the 16-year civil war. Losing this land to an LAI twenty years later must have had a profound impact on their lives. As Norfolk and Hanlon (2012) show, in some cases land users had been promised new land and support for agricultural production but had never received it. Widespread resentment at the loss of land also explains the large number of conflicts reported by the respondents in our study.

When we asked respondents directly whether the LAI had had any impact on the environment, $36 \%$ said yes. This was mostly the case around LAI2, where $55 \%$ of respondents $(n=20)$ reported environmental impacts. The main environmental impact across both study areas, mentioned by $12 \%$ of respondents ( $\mathrm{n}=95)$, was that the LAIs had blocked their access to water sources. This had occurred around several of the LAIs and confirms the common assumption and findings from other studies that many LAIs occupy not only land but also water resources (Breu et al., 2016; Smaller et al., 2015; Woodhouse, 2012; Zaehringer, Wambugu, Kiteme, \& Eckert, 2018). Air pollution (5\%) and water pollution from pesticides (4\%) were the second and third most common environmental impacts mentioned.

A total $31 \%$ of respondents $(n=100)$ stated that the LAI in their vicinity had had an impact on people's health. This was by far most prominent around the soya-producing LAI2, where 58\% of respondents $(n=19)$ said so. The main issues around this LAI were air pollution $(26 \%, n=19)$, followed by cold and diarrhoea (21\%). The problem of aerial pesticide spraying by LAI1 and its impacts on neighbouring farmers' crops and people's health was also reported by Mandamule (2016) and UNAC and GRAIN (2015). Other issues mentioned by two or fewer respondents included hypertension due to stress over cropland loss, respiratory problems, 
infectious diseases, muscle pain, and lack of help when people fell ill. However, these were mentioned by respondents near one of the LAIs in Guruè where the issue of land loss appeared to be particularly conflictive, so the perception of health impacts may have been influenced by these land conflicts. Single respondents also reported positive impacts of LAIs on health, such as better nutrition, improved health infrastructure, and increased food supply.

As many as $42 \%$ of all respondents $(n=101)$ said that the LAI had improved infrastructure in their community. This was particularly pronounced around LAI1 $(67 \%, n=15)$, where the two main infrastructure projects were school buildings (57\%, $\mathrm{n}=15)$ and a hospital (43\%). However, a working paper by Cabral and Norfolk (2016) reports these projects to have failed. We have not been able to establish whether the buildings had actually been under construction at the time of our interviews or whether our respondents had mentioned them in anticipation of future benefits. Respondents in the Monapo study area (n=52) also highlighted improved water supply (23\%), a hospital (20\%) - although they said it was not operational - and school buildings $(13.5 \%)$

Conflicts between communities and LAI companies were very widespread, with $78 \%$ of all respondents mentioning them. The majority of respondents around all LAIs except LAI1 confirmed that conflicts between the communities and the LAI companies were ongoing. Only few respondents specified the types of conflicts; they included conflicts over water, over compensation for lost land, over the closure of access to land, and others. When asked whether they would generally prefer the LAI in their vicinity to stay or to leave, $54 \%$ of all respondents ( $n=101$ ) wished for the LAI to leave. These results show that the perceived positive impacts on infrastructure around some of the LAIs as well as the income opportunities the LAIs provided could not make up for small-scale farmers' loss of land and access to natural resources. Only around LAI1 did a majority of respondents $(73 \%, \mathrm{n}=15)$ wish for the LAI to remain. This is rather surprising, as reports of ongoing conflicts between the company running LAI1 and neighbouring land users are common (Mandamule, 2016; UNAC \& GRAIN, 2015). The reason 
for this difference in findings remains unclear. We assume that either our respondents' views do not reflect those of the overall population, or the conflicts have been mitigated or solved in the meantime. Nevertheless, this finding suggests that a beneficial coexistence of LAIs and small-scale farmers is possible in the Nacala corridor if small-scale farmers perceive the benefits from LAIs to outweigh the costs.

\section{Conclusion}

With this study, we add important empirical evidence to a scarce but growing body of literature on the impacts of LAIs on small-scale farmers in developing countries. Establishing causal links between the establishment of an LAI and land use change in the surrounding area by means of remote sensing and spatial analysis alone is challenging. Our interdisciplinary assessment, which combines in-depth qualitative case studies with quantitative information on land cover and land use change from earth observation data, is in line with the aim of land system science to shed light on the context-specific causes and consequences of land use change. Our evidence of small-scale farmers' cropland being displaced into forest - and thus of indirect land use changes due to LAIs - is an important contribution to an understudied but increasingly relevant dimension of land system science (Liu et al., 2018; Meyfroidt, Lambin, Erb, \& Hertel, 2013). In this respect, we wish to underline the need for impact assessments of LAIs to become more holistic and include direct and indirect impacts in all dimensions of sustainability. Considering economic impacts alone does not do justice to the highly complex social-ecological systems in place.

Our study shows that LAIs producing food crops for international and national markets in the Mozambican Nacala development corridor have manifold impacts on the lives of local smallscale farmers, land use, and the surrounding landscapes. 
First, the establishment of LAIs in the Nacala corridor of Mozambique has caused many smallscale farmers to lose cropland that was essential to their livelihoods. In this highly poverty- and disaster-prone rural context, with people still recovering from decades of civil war, land is by far the most important asset for most rural households. Although a number of households in our study received some small compensation for their loss of cropland from the respective LAI companies, this was just a drop in the ocean compared to the true value of the land. Besides having lost land to an LAI, many small-scale farmers also complained that the LAIs had blocked their access to water sources and their footpaths. The fact that many Mozambican small-scale farmers lost access to land and water and experienced a reduction in the size and quality of their cropland as a result of claims on land for the production of food and animal feed crops that serve demands by predominantly urban populations in developed countries raises important questions of social and environmental justice (Martinez-Alier, Temper, Bene, \& Scheidel, 2016) that require further exploration.

Second, besides this direct negative socio-economic impact on farmers' livelihoods, an important indirect consequence of LAIs established on previous small-scale cropland is the displacement of small-scale farmers' land uses into previously forested areas, which can severely compromise the ecological sustainability of the respective LAIs. The indirect land use changes induced by LAIs in the Nacala corridor add to the existing trend of cropland expansion and put further pressure on the biodiversity-rich miombo woodlands (Chirwa, Syampungani, \& Geldenhuys, 2008) in this area. Furthermore, several LAI companies contributed to deforestation directly by clearing woody vegetation themselves. This suggests that future environmental impact assessments need to consider both direct and indirect effects of LAIs on the environment.

Third, many local households expressed a strong wish for employment with LAI companies. Job opportunities exist but are insufficient and unstable. Positive spillovers in terms of the transfer of knowledge about agricultural practices from LAIs were reported by some of the 
respondents who had worked for one of the LAI companies; and some of the LAI companies had invested in infrastructure for the surrounding communities. Nevertheless, small-scale farmers' overall perception of LAIs was mostly negative, and many of them wished for the LAIs to abandon their operations in the Nacala corridor. This conflictive situation can probably only be improved if the existing injustices around the occupation of land are resolved through fair compensation and adequate support of small-scale farmers by LAI companies and the government.

Fourth, our results show that a progressive land law alone cannot guarantee that private investments in land automatically contribute to poverty alleviation and sustainable development. As land system scientists who see themselves as change agents and wish to advance transformations towards sustainability, we believe it is vital to foster exchanges on an equal footing and social learning among the different actors involved in and affected by LAIs. Only through jointly negotiated transformative actions can Mozambique’s progressive land law lead towards more sustainable development in the Nacala corridor that would benefit smallscale farmers, LAI companies, and the environment all at once. This is especially important in view of future ProSAVANA activities, which might aggravate the situation for small-scale farmers and the environment in the Nacala corridor unless sustainability considerations are taken seriously. 


\section{Acknowledgements}

The research for this publication was conducted as part of the BELMONT Forum and FACCEJPI project “African Food, Agriculture, Land and Natural Resource Dynamics, in the context of global agro-food-energy system changes (AFGROLAND)” (Grant Number: 40FA40_160405). The project is funded by the Swiss National Science Foundation, the French National Research Agency, and the South African National Research Foundation. We are grateful to the 101 respondents who took the time to answer our questions, and to the research assistants who conducted the interviews. We thank Magalie Bourblanc for sharing her knowledge on investment policies in Mozambique. We also thank Marlène Thibault for copyediting our manuscript and the two anonymous reviewers for their constructive and useful comments. 


\section{References}

Acheampong, E., \& Campion, B. B. (2014). The Effects of Biofuel Feedstock Production on Farmers’ Livelihoods in Ghana: The Case of Jatropha curcas. Sustainability, 6(7), 4587-4607. https://doi.org/10.3390/su6074587

Amanor, K. S., \& Chichava, S. (2016). South-South Cooperation, Agribusiness, and African Agricultural Development: Brazil and China in Ghana and Mozambique. World Development, 81, 13-23. https://doi.org/10.1016/j.worlddev.2015.11.021

Andrade de Sá, S., Palmer, C., \& di Falco, S. (2013). Dynamics of indirect land-use change: Empirical evidence from Brazil. Journal of Environmental Economics and Management, 65(3), 377-393. https://doi.org/10.1016/j.jeem.2013.01.001

Ariti, A. T., van Vliet, J., \& Verburg, P. H. (2015). Land-use and land-cover changes in the Central Rift Valley of Ethiopia: Assessment of perception and adaptation of stakeholders. Applied Geography, 65, 28-37. https://doi.org/10.1016/j.apgeog.2015.10.002

Barretto, A. G. O. P., Berndes, G., Sparovek, G., \& Wirsenius, S. (2013). Agricultural intensification in Brazil and its effects on land-use patterns: an analysis of the 19752006 period. Global Change Biology, 19(6), 1804-1815. https://doi.org/10.1111/gcb.12174

Bergtold, J. S., Caldas, M. M., Sant’anna, A. C., Granco, G., \& Rickenbrode, V. (2017). Indirect land use change from ethanol production: the case of sugarcane expansion at the farm level on the Brazilian Cerrado. Journal of Land Use Science, 12(6), 442-456. https://doi.org/10.1080/1747423X.2017.1354937

Breiman, L. (2001). Random Forests. Machine Learning, 45(1), 5-32. https://doi.org/10.1023/A:1010933404324 
Breu, T., Bader, C., Messerli, P., Heinimann, A., Rist, S., \& Eckert, S. (2016). Large-Scale Land Acquisition and Its Effects on the Water Balance in Investor and Host Countries. PLOS ONE, 11(3), e0150901. http://dx.doi.org/10.1371/journal.pone.0150901

Cabral, L. (2009). Sector budget support in practice. Desk study. Agriculture sector in Mozambique. London, UK: ODI and Mokoro.

Cabral, L., \& Norfolk, S. (2016). Inclusive land governance in Mozambique: good law, bad politics? (IDS Working Paper No. Volume 2016 No 478). Brighton, UK, and Bern, Switzerland: Institute of Development Studies and Swiss Agency for Development and Cooperation.

Chirwa, P. W., Syampungani, S., \& Geldenhuys, C. J. (2008). The ecology and management of the Miombo woodlands for sustainable livelihoods in southern Africa: the case for non-timber forest products. Southern Forests: A Journal of Forest Science, 70(3), 237-245. https://doi.org/10.2989/SF.2008.70.3.7.668

Collier, P., \& Dercon, S. (2014). African Agriculture in 50 Years: Smallholders in a Rapidly Changing World? World Development, 63, 92-101. https://doi.org/10.1016/j.worlddev.2013.10.001

Congalton, R. G., \& Green, K. (2008). Assessing the accuracy of remotely sensed data: principles and practices. Boca Raton, USA: CRC press.

Cooperação Triangular para o Desenvolvimento Agrário da Savana Tropical em Moçambique. (2016). Plano Director para o Desenvolvimento Agrario do Corredor de Nacala. Versao Provisoria. Maputo, Mozambique: Ministério da Agricultura e Segurança Alimentar.

De Renzio, P., \& Hanlon, J. (2007). Contested sovereignty in Mozambique: The dilemmas of aid dependence. (Global Economic Governance Programme Working Paper No. 2007/25). London, UK: University College. Retrieved from 
http://www.globaleconomicgovernance.org/sites/geg/files/De\%20Renzio\%20Hanlon GEG\%20WP\%202007 25.pdf

Deininger, K., \& Byerlee, D. (2011). Rising global interest in farmland: can it yield sustainable and equitable benefits? World Bank Publications.

Deininger, K., \& Xia, F. (2016). Quantifying Spillover Effects from Large Land-based Investment: The Case of Mozambique. World Development, 87, 227-241. http://dx.doi.org/10.1016/j.worlddev.2016.06.016

Di Matteo, F., Otsuki, K., \& Schoneveld, G. (2016). Soya bean expansion in Mozambique: exploring the inclusiveness and viability of soya business models as an alternative to the land grab. The Public Sphere, 61-86.

Di Matteo, F., \& Schoneveld, G. (2016). Agricultural investments in Mozambique. An analysis of investment trends, business models and social and environmental conduct (Working Paper 201). Bogor, Indonesia: CIFOR.

Eckert, S., Kiteme, B., Njuguna, E., \& Zaehringer, J. G. (2017). Agricultural Expansion and Intensification in the Foothills of Mount Kenya: A Landscape Perspective. Remote Sensing, 9(8), 784. http://dx.doi.org/10.3390/rs9080784

Finkbeiner, M. (2014). Indirect land use change - Help beyond the hype? Biomass and Bioenergy, 62, 218-221. https://doi.org/10.1016/j.biombioe.2014.01.024

German, L., Cavane, E., Sitoe, A., \& Braga, C. (2016). Private investment as an engine of rural development: A confrontation of theory and practice for the case of Mozambique. Land Use Policy, 52, 1-14. https://doi.org/10.1016/j.landusepol.2015.11.012

German, L., Schoneveld, G., \& Pacheco, P. (2011). The social and environmental impacts of biofuel feedstock cultivation: Evidence from multi-site research in the forest frontier. Ecology and Society, 16(3), 24. http://dx.doi.org/10.5751/ES-04309-160324 
Griffiths, P., Kuemmerle, T., Baumann, M., Radeloff, V. C., Abrudan, I. V., Lieskovsky, J., ... Hostert, P. (2014). Forest disturbances, forest recovery, and changes in forest types across the Carpathian ecoregion from 1985 to 2010 based on Landsat image composites. Remote Sensing of Environment, 151, 72-88. https://doi.org/10.1016/j.rse.2013.04.022

Griffiths, P., Müller, D., Kuemmerle, T., \& Hostert, P. (2013). Agricultural land change in the Carpathian ecoregion after the breakdown of socialism and expansion of the European Union. Environmental Research Letters, 8(4), 1-12. https://doi.org/10.1088/17489326/8/4/045024

Hanlon, J. (2018, March 26). Mozambique: Another Norfund Fiasco as Matanuska Goes Bust. Retrieved July 23, 2018, from https://allafrica.com/stories/201803260872.html

Hofmann, K. (2013). Economic transformation in Mozambique. Implications for human security. Berlin, Germany: Friedrich-Ebert-Stiftung.

IAASTD. (2009). Agriculture at a Crossroads. International assessment of agricultural knowledge, science and technology for development (IAASTD). Sub-Saharan Africa (SSA) Report. Washington. Retrieved from https://www.globalagriculture.org/fileadmin/files/weltagrarbericht/IAASTDBerichte/S ubglobalReportSubSaharanAfrica.pdf

Ikegami, K. (2015). Corridor Development and Foreign Investment in Agriculture: Implications of the ProSAVANA Programme in Northern Mozambique. In Land grabbing, conflict and agrarian-environmental transformations: perspectives from East and Southeast Asia. Thailand, Chiang Mai University.

INE. (2012). Estatisticas do Distrito Monapo. Maputo, Mozambique: Instituto Nacional de Estatistica. 
Joala, R., Zamchiya, Ntauzi, C., Musole, P., \& Katebe, C. (2016). Changing agro-food systems. The impact of big agro-investors on food rights. Case studies in Mozambique and Zambia. (p. 106). Cape Town: PLAAS.

Lambin, E. F., \& Geist, H. J. (2008). Land-Use and Land-Cover Change: Local Processes and Global Impacts. Berlin Heidelberg: Springer Science \& Business Media.

Lambin, E. F., \& Meyfroidt, P. (2011). Global land use change, economic globalization, and the looming land scarcity. Proceedings of the National Academy of Sciences, 108(9), 3465-3472. https://doi.org/10.1073/pnas.1100480108

Liu, J., Dou, Y., Batistella, M., Challies, E., Connor, T., Friis, C., ... Sun, J. (2018). Spillover systems in a telecoupled Anthropocene: typology, methods, and governance for global sustainability. Current Opinion in Environmental Sustainability, 33, 58-69. https://doi.org/10.1016/j.cosust.2018.04.009

Mandamule, U. (2016). Tipologia dos conflitos sobre a ocupaçao da terra em Moçambique. Maputo, Mozambique: Observador Rural.

Manhique, A. J., \& Zucule, J. (2012). Atlas de Precipitação Moçambique. Maputo, Mozambique: INAM, UNEP, UNDP.

Martinez-Alier, J., Temper, L., Bene, D. D., \& Scheidel, A. (2016). Is there a global environmental justice movement? The Journal of Peasant Studies, 43(3). https://doi.org/10.1080/03066150.2016.1141198

Meyfroidt, P. (2015). Approaches and terminology for causal analysis in land systems science. Journal of Land Use Science, 0(0), 1-27. https://doi.org/10.1080/1747423X.2015.1117530

Meyfroidt, P., Lambin, E. F., Erb, K.-H., \& Hertel, T. W. (2013). Globalization of land use: distant drivers of land change and geographic displacement of land use. Current Opinion in Environmental Sustainability, 5(5), 438-444. https://doi.org/10.1016/j.cosust.2013.04.003 
No to ProSavana Campaign. (2018, June 13). GRAIN — Campaign reiterates opposition to ProSavana in Mozambique. Retrieved July 30, 2018, from https://www.grain.org/bulletin_board/entries/5968-campaign-reiterates-opposition-toprosavana-in-mozambique

Nolte, K., Chamberlain, W., \& Giger, M. (2016). International Land Deals for Agriculture. Fresh insights from the Land Matrix: Analytical Report II.

Bern/Montpellier/Hamburg/Pretoria: Centre for Development and Environment; Centre de coopération internationale en recherche agronomique pour le développement; German Institute of Global and Area Studies; University of Pretoria; Bern Open Publishing. Retrieved from https://boris.unibe.ch/85304/1/land_matrix_2016_analytical_report_draft_ii.pdf

Norfolk, S., \& Hanlon, J. (2012). Confrontation Between Peasant Producers and Investors in Northern Zambézia, Mozambique, in the Context of Profit Pressures on European Investors. In Annual World Bank Conference on Land and Poverty. Washington DC: The World Bank.

Phalan, B., Bertzky, M., Butchart, S. H. M., Donald, P. F., Scharlemann, J. P. W., Stattersfield, A. J., \& Balmford, A. (2013). Crop Expansion and Conservation Priorities in Tropical Countries. PLOS ONE, 8(1), e51759. https://doi.org/10.1371/journal.pone.0051759

R Core Team. (2015). R: A language and environment for statistical computing. Vienna, Austria: R Foundation for Statistical Computing. Retrieved from https://www.Rproject.org/

Reenberg, A. (2009). Land system science: handling complex series of natural and socioeconomic processes. Journal of Land Use Science, 4(1-2), 1-4. https://doi.org/10.1080/17474230802645618 
Republica de Moçambique, Ministério da Agricultura. (2011). Plano Estrategico Para O Desenvolvimento do Sector Agrario PEDSA. 2011-2020. Maputo, Mozambique: Republica de Moçambique, Ministério da Agricultura.

Republica de Moçambique, Ministério da Agricultura. (2013). Plano Nacional De Investimento Do Sector Agrario PNISA. 2013-2017. Maputo, Mozambique: Republica de Moçambique, Ministério da Agricultura.

Rogan, J., \& Chen, D. (2004). Remote sensing technology for mapping and monitoring landcover and land-use change. Progress in Planning, 61(4), 301-325. https://doi.org/10.1016/S0305-9006(03)00066-7

Rulli, M. C., \& D’Odorico, P. (2017). Environmental Impacts of Large-Scale Land Acquisitions in Africa. In C. Fiamingo (Ed.), Problems and progress in land, water and resources rights at the beginning of the third millennium. Broni PV: Edizione Altravista. Retrieved from https://play.google.com/books/reader?id=jOUpDwAAQBAJ\&printsec=frontcover\&ou tput=reader\&hl=de\&pg=GBS.PA133

Scharsich, V., Mtata, K., Hauhs, M., Lange, H., \& Bogner, C. (2017). Analysing land cover and land use change in the Matobo National Park and surroundings in Zimbabwe. Remote Sensing of Environment, 194, 278-286.

https://doi.org/10.1016/j.rse.2017.03.037

Schoneveld, G. C., German, L., \& Nutakor, E. (2011). Land-based Investments for Rural Development? A Grounded Analysis of the Local Impacts of Biofuel Feedstock Plantations in Ghana. Ecology and Society, 16(4). http://dx.doi.org/10.5751/ES04424-160410

Searchinger, T., Heimlich, R., Houghton, R. A., Dong, F., Elobeid, A., Fabiosa, J., ... Yu, T.H. (2008). Use of U.S. Croplands for Biofuels Increases Greenhouse Gases Through 
Emissions from Land-Use Change. Science, 319(5867), 1238-1240.

https://doi.org/10.1126/science.1151861

Shankland, A., \& Gonçalves, E. (2016). Imagining Agricultural Development in South-South Cooperation: The Contestation and Transformation of ProSAVANA. World Development, 81, 35-46. https://doi.org/10.1016/j.worlddev.2016.01.002

Smaller, C., Speller, W., Mirza, H., Bernasconi-Osterwalder, N., \& Dixie, G. (2015). Investment Contracts for Agriculture: Maximizing Gains and Minimizing Risks. (Agriculture Global Practice Discussion Paper 3). Washington D.C., New York, Winnepeg: World Bank Group, United Nations, International Institute for Sustainable Development.

The World Bank. (2011). Rising global interest in farmland. Washington D.C.: The World Bank.

Triangular Cooperation for Agricultural Development of the Tropical Savannah in Mozambique. (2012). Support Agriculture Development Master Plan in The Nacala Corridor in Mozambique (PROSAVANA-PD). Interim Report. Data collection and analysis of agriculture in Nacala Corridor. Maputo, Mozambique and Tokyo, Japan: MINAG, DPAs, Oriental Consultants Co. Ltd., NTC International Co. Ltd., Task Co. Ltd. Retrieved from http://www.prosavana.gov.mz/wp-content/uploads/2015/04/forHP-ITR1-Chap-0-cover1.pdf

Turner, B. L., Lambin, E. F., \& Reenberg, A. (2007). The emergence of land change science for global environmental change and sustainability. Proceedings of the National Academy of Sciences, 104(52), 20666-20671. https://doi.org/10.1073/pnas.0704119104

UNAC, \& GRAIN. (2015). The Land Grabbers of the Nacala Corridor. A new era of struggle against colonial plantations in Northern Mozambique. Barcelona, Spain. 
UNDP. (2016). Human Development Report 2016. Human Development for Everyone. New York: United Nations Development Programme.

Verburg, P. H., Crossman, N., Ellis, E. C., Heinimann, A., Hostert, P., Mertz, O., ... Zhen, L. (2015). Land system science and sustainable development of the earth system: A global land project perspective. Anthropocene. https://doi.org/10.1016/j.ancene.2015.09.004

von Maltitz, G. P., Gasparatos, A., Fabricius, C., Morris, A., \& Willis, K. J. (2016). Jatropha cultivation in Malawi and Mozambique: impact on ecosystem services, local human well-being, and poverty alleviation. Ecology and Society, 21(3). http://dx.doi.org/10.5751/ES-08554-210303

White, B., Jr, S. M. B., Hall, R., Scoones, I., \& Wolford, W. (2012). The new enclosures: critical perspectives on corporate land deals. The Journal of Peasant Studies, 39(3-4), 619-647. https://doi.org/10.1080/03066150.2012.691879

Wise, T. (2014, December 20). What Happened to the Biggest Land Grab in Africa? Searching for ProSavana in Mozambique.

Woodhouse, P. (2012). Foreign agricultural land acquisition and the visibility of water resource impacts in Sub-Saharan Africa. Water Alternatives, 5(2), 208.

Wulder, M. A., White, J. C., Goward, S. N., Masek, J. G., Irons, J. R., Herold, M., ... Woodcock, C. E. (2008). Landsat continuity: Issues and opportunities for land cover monitoring. Remote Sensing of Environment, 112(3), 955-969. https://doi.org/10.1016/j.rse.2007.07.004

Zaehringer, J. G., Wambugu, G., Kiteme, B., \& Eckert, S. (2018). How do large-scale agricultural investments affect land use and the environment on the western slopes of Mount Kenya? Empirical evidence based on small-scale farmers’ perceptions and remote sensing. Journal of Environmental Management, 213, 79-89. https://doi.org/10.1016/j.jenvman.2018.02.019 
Zhu, Z., \& Woodcock, C. E. (2014). Continuous change detection and classification of land cover using all available Landsat data. Remote Sensing of Environment, 144, 152-171. https://doi.org/10.1016/j.rse.2014.01.011 
Table 1: Characteristics of LAIs and numbers of household interviews conducted. Sources: own data; UNAC and GRAIN (2015); Joala et al. (2016); Triangular Cooperation for Agricultural Development of the Tropical Savannah in Mozambique (2012).

\begin{tabular}{|c|c|c|c|c|c|c|}
\hline & Case 1 & Case 2 & Case 3 & & Case 4 & \\
\hline & LAI1 & LAI2 & LAI3 & LAI4 & LAI5 & LAI6 \\
\hline District & Guruè & Guruè & Guruè & Monapo & Monapo & Monapo \\
\hline $\begin{array}{l}\text { Crops } \\
\text { produced }\end{array}$ & $\begin{array}{l}\text { Soy, rice, } \\
\text { maize }\end{array}$ & Soy, maize & $\begin{array}{c}\text { Macadamia, } \\
\text { maize }\end{array}$ & Banana & Soy & $\begin{array}{l}\text { Vegetables } \\
\text { etc. }\end{array}$ \\
\hline $\begin{array}{l}\text { Investors' } \\
\text { countries of } \\
\text { origin }\end{array}$ & $\begin{array}{c}\text { Portugal, } \\
\text { Mozambique } \\
\text {, Brazil }\end{array}$ & $\begin{array}{c}\text { Mauritius/ } \\
\text { Netherlands }\end{array}$ & South Africa & $\begin{array}{l}\text { Mauritius/ } \\
\text { Norway }\end{array}$ & South Africa & Mauritius \\
\hline $\begin{array}{l}\text { Irrigation } \\
\text { water sources }\end{array}$ & $\begin{array}{l}\text { Information } \\
\text { unavailable }\end{array}$ & No irrigation & River & River & River & $\begin{array}{l}\text { Artificial } \\
\text { pond }\end{array}$ \\
\hline $\begin{array}{l}\text { Rainfall } \\
\text { (mm/year) }\end{array}$ & 800-1000 & $1000-1200$ & $1200-1400$ & $1000-1200$ & 1000-1200 & $1000-1200$ \\
\hline $\begin{array}{l}\text { Year } \\
\text { established }\end{array}$ & 2012 & 2009 & 2012 & 2007 & 2013 & 2012 \\
\hline $\begin{array}{l}\text { Numbers of } \\
\text { interviews } \\
\text { conducted }\end{array}$ & 15 & 20 & 14 & 19 & 20 & 13 \\
\hline
\end{tabular}


Table 2: General information on households and their involvement with LAIs. Values indicate per cent of respondents per case and overall unless indicated otherwise.

\begin{tabular}{|c|c|c|c|c|c|}
\hline & Overall & Case 1 & Case 2 & Case 3 & Case 4 \\
\hline Origin of respondent & $(n=101)$ & $(n=15)$ & $(n=20)$ & $(n=14)$ & $(n=52)$ \\
\hline Native & 44.6 & 26.7 & 25.0 & 35.7 & 59.6 \\
\hline Immigrant & 55.4 & 73.3 & 75.0 & 64.3 & 40.4 \\
\hline Reasons for moving to present location & $(n=56)$ & $(n=11)$ & $(n=15)$ & $(n=9)$ & $(n=21)$ \\
\hline Found employment with LAI & 8.9 & 18.2 & 6.7 & 11.1 & 4.8 \\
\hline Looking for work & 16.1 & 9.1 & 13.3 & 11.1 & 23.8 \\
\hline Other & 58.9 & 72.7 & 80.0 & 66.7 & 33.3 \\
\hline $\mathrm{n} / \mathrm{a}$ & 16.1 & 0.0 & 0.0 & 2.1 & 38.1 \\
\hline Farming activities (several responses possible) & $(n=101)$ & $(n=15)$ & $(n=20)$ & $(n=14)$ & $(n=52)$ \\
\hline Subsistence farming & 99.0 & 100.0 & 100.0 & 92.9 & 100 \\
\hline Commercial farming & 87.1 & 86.7 & 90.0 & 64.3 & 92.3 \\
\hline Size of cultivated cropland (ha) & $(n=99)$ & $(n=15)$ & $(n=20)$ & $(n=13)$ & $(n=51)$ \\
\hline Mean (SD) & $2.7(1.9)$ & $2.3(1.8)$ & $3(2.3)$ & $1.8(1.8)$ & $2.8(1.8)$ \\
\hline Involvement with LAIs & $(n=101)$ & $(n=15)$ & $(n=20)$ & $(n=14)$ & $(n=52)$ \\
\hline Presently employed & 21.8 & 26.7 & 35.0 & 35.7 & 11.5 \\
\hline Previously employed & 23.8 & 33.3 & 25.0 & 42.9 & 15.4 \\
\hline Never employed & 54.5 & 40.0 & 40.0 & 21.4 & 73.1 \\
\hline Reasons for never having been involved with LAIs & $(n=55)$ & $(n=6)$ & $(n=8)$ & $(n=3)$ & $(n=38)$ \\
\hline Difficult to find job & 49.1 & 16.7 & 25.0 & 33.3 & 60.5 \\
\hline Discouraged by bad working conditions & 21.8 & 16.7 & 62.5 & 0.0 & 15.8 \\
\hline Prefer to work on own farm & 9.1 & 50.0 & 12.5 & 0.0 & 2.6 \\
\hline No interest & 5.5 & 16.7 & 0.0 & 0.0 & 5.3 \\
\hline Other & 5.5 & 0.0 & 0.0 & 33.3 & 5.3 \\
\hline $\mathrm{n} / \mathrm{a}$ & 9.1 & 0.0 & 0.0 & 33.3 & 10.5 \\
\hline $\begin{array}{l}\text { Impact of LAI employment (current or previous) on labour } \\
\text { availability for own farming activities }\end{array}$ & $(n=46)$ & $(n=9)$ & $(n=12)$ & $(n=11)$ & $(n=14)$ \\
\hline Labour availability not affected & 58.7 & 44.4 & 58.3 & 63.6 & 64.3 \\
\hline Not enough labour available & 15.2 & 33.3 & 16.7 & 9.1 & 7.1 \\
\hline More labour available (able to hire someone) & 2.2 & 0.0 & 0.0 & 0.0 & 7.1 \\
\hline $\mathrm{n} / \mathrm{a}$ & 23.9 & 22.2 & 25.0 & 27.3 & 21.4 \\
\hline Spillovers in terms of agricultural knowledge and technology & $(n=46)$ & $(n=9)$ & $(n=12)$ & $(\mathrm{n}=11)$ & $(n=14)$ \\
\hline Yes & 32.6 & 55.6 & 16.7 & 27.3 & 35.7 \\
\hline No & 54.3 & 22.2 & 66.7 & 63.6 & 57.1 \\
\hline $\mathrm{n} / \mathrm{a}$ & 13.1 & 22.2 & 16.7 & 9.1 & 7.1 \\
\hline
\end{tabular}


Table 3: Small-scale farmers' statements regarding net changes in the size of their cropland, displacement of their land uses by LAIs, and perceived changes in tree cover in the LAIs' surroundings. Values indicate per cent of respondents per case and overall unless indicated otherwise.

\begin{tabular}{|c|c|c|c|c|c|}
\hline & Overall & Case 1 & Case 2 & Case 3 & Case 4 \\
\hline Net changes in cropland size & $(n=101)$ & $(n=15)$ & $(n=20)$ & $(n=14)$ & $(n=52)$ \\
\hline Change in cropland size & 61.4 & 66.7 & 75.0 & 85.7 & 48.1 \\
\hline Increase in cropland size & 14.9 & 33.3 & 15.0 & 14.3 & 9.6 \\
\hline Decrease in cropland size & 46.5 & 33.3 & 60.0 & 71.4 & 38.5 \\
\hline Reasons for increase & $(n=15)$ & $(n=5)$ & $(n=3)$ & $(n=2)$ & $(n=5)$ \\
\hline Increase overall production & 80.0 & 60.0 & 100.0 & 100.0 & 80.0 \\
\hline Leave part of land fallow & 13.3 & 40.0 & 0.0 & 0.0 & 0.0 \\
\hline $\mathrm{n} / \mathrm{a}$ & 6.7 & 0.0 & 0.0 & 0.0 & 20.0 \\
\hline Reasons for decrease & $(n=47)$ & $(n=5)$ & $(n=12)$ & $(n=10)$ & $(n=20)$ \\
\hline Land taken by LAI & 91.5 & 100.0 & 91.7 & 80.0 & 95.0 \\
\hline Distribute land to heirs & 2.1 & 0.0 & 0.0 & 0.0 & 5.0 \\
\hline $\mathrm{n} / \mathrm{a}$ & 6.4 & 0.0 & 8.3 & 20.0 & 0.0 \\
\hline Increase of cropland at the expense of & $(n=15)$ & $(n=5)$ & $(n=3)$ & $(n=2)$ & $(n=5)$ \\
\hline Forest & 66.7 & 80.0 & 66.7 & 100.0 & 40.0 \\
\hline Cropland/bushland & 26.7 & 0.0 & 33.3 & 0.0 & 60.0 \\
\hline $\mathrm{n} / \mathrm{a}$ & 6.7 & 20.0 & 0.0 & 0.0 & 0.0 \\
\hline Displacement of land uses by LAI & $(n=101)$ & $(n=15)$ & $(n=20)$ & $(n=14)$ & $(n=52)$ \\
\hline Land taken by LAI & 50.5 & 33.3 & 75.0 & 78.6 & 38.5 \\
\hline Consequences of land taken by LAI & $(n=51)$ & $(n=5)$ & $(n=15)$ & $(n=11)$ & $(n=20)$ \\
\hline Received compensation & 45.1 & 100.0 & 100.0 & 18.2 & 5.0 \\
\hline Acquired new land & 62.7 & 60.0 & 80.0 & 45.5 & 60.0 \\
\hline Did not acquire new land & 37.3 & 40.0 & 20.0 & 54.5 & 40.0 \\
\hline Previous land use of acquired land & $(n=32)$ & $(n=3)$ & $(n=12)$ & $(n=5)$ & $(\mathrm{n}=12)$ \\
\hline Forest & 62.5 & 100.0 & 58.3 & 40.0 & 66.7 \\
\hline Cropland/bushland & 34.4 & 0.0 & 41.7 & 60.0 & 25.0 \\
\hline $\mathrm{n} / \mathrm{a}$ & 3.1 & 0.0 & 0.0 & 0.0 & 8.3 \\
\hline Difference between newly acquired and lost cropland & $(n=32)$ & $(n=3)$ & $(n=12)$ & $(n=5)$ & $(n=12)$ \\
\hline Lower soil quality & 65.6 & 100.0 & 66.7 & 80.0 & 50.0 \\
\hline Higher soil quality & 6.3 & 0.0 & 8.3 & 20.0 & 0.0 \\
\hline Higher flood risk & 6.3 & 0.0 & 16.7 & 0.0 & 0.0 \\
\hline Tree trunks hamper ploughing & 3.1 & 0.0 & 8.3 & 0.0 & 0.0 \\
\hline Further away from river (irrigation source) & 3.1 & 0.0 & 0.0 & 0.0 & 8.3 \\
\hline No difference & 9.4 & 0.0 & 0.0 & 0.0 & 25.0 \\
\hline $\mathrm{n} / \mathrm{a}$ & 6.3 & 0.0 & 0.0 & 0.0 & 16.7 \\
\hline Size of land taken by LAI (ha) & $(n=50)$ & $(n=5)$ & $(n=15)$ & $(n=10)$ & $(n=20)$ \\
\hline Minimum & 0.5 & 0.5 & 1.0 & 0.5 & 0.5 \\
\hline Maximum & 25.0 & 5.0 & 25.0 & 2.0 & 5.0 \\
\hline Mean (SD) & $3.2(4)$ & $3.0(1.8)$ & $5.9(6.4)$ & $1.3(0.6)$ & $2.1(1.2)$ \\
\hline Net change of land size after land taken by LAI (ha) & $(n=48)$ & $(n=5)$ & $(n=14)$ & $(n=10)$ & $(n=19)$ \\
\hline Mean (SD) & $-1.8(3.4)$ & $-1.8(1.8)$ & $-3.7(5.5)$ & $-1.0(0.7)$ & $-0.7(2)$ \\
\hline \multirow[t]{2}{*}{ Net decrease of land size after land taken by LAI } & $(n=51)$ & $(n=5)$ & $(n=15)$ & $(n=11)$ & $(n=20)$ \\
\hline & 74.5 & 100 & 80.0 & 81.8 & 60.0 \\
\hline Perceived changes in tree cover & $(n=101)$ & $(n=15)$ & $(n=20)$ & $(n=14)$ & $(n=52)$ \\
\hline Increase in tree cover & 1.0 & 0.0 & 0.0 & 0.0 & 1.9 \\
\hline Decrease in tree cover & 76.2 & 73.3 & 70.0 & 71.4 & 80.8 \\
\hline No change in tree cover & 22.8 & 26.7 & 30.0 & 28.6 & 17.3 \\
\hline \multicolumn{6}{|l|}{ Remaining natural tree cover in landscape } \\
\hline Yes & 53.5 & 66.7 & 40.0 & 35.7 & 59.6 \\
\hline No & 42.6 & 26.7 & 55.0 & 57.1 & 38.5 \\
\hline $\mathrm{n} / \mathrm{a}$ & 4.0 & 6.7 & 5.0 & 7.1 & 1.9 \\
\hline Reasons for decrease in tree cover & $(n=77)$ & $(n=11)$ & $(n=14)$ & $(n=10)$ & $(n=42)$ \\
\hline
\end{tabular}


Cropland expansion

Harvest of timber for construction, energy, etc.

Population growth

LAI cut trees

$\mathrm{n} / \mathrm{a}$

\begin{tabular}{cc}
76.6 & 63. \\
9.1 & 27.3 \\
3.9 & 0.0 \\
7.8 & 0.0 \\
2.6 & 9.1 \\
\hline
\end{tabular}

80.0

10.0

0.0

0.0 $\begin{array}{lll}9.1 & 0.0 & 10.0\end{array}$

76.2

7.1

$\begin{array}{llll}0.0 & 7.1 & 0.0 & 4.8 \\ 0.0 & 7.1 & 0.0 & 11.9\end{array}$


Table 4: Net changes in main LULC classes observed by means of remote sensing. Percentages present net changes as a share of the total area analysed per case or overall, respectively.

\begin{tabular}{|c|c|c|c|c|c|c|c|c|c|c|}
\hline \multirow[b]{2}{*}{ Net changes } & \multicolumn{2}{|c|}{ Overall } & \multicolumn{2}{|c|}{ Case 1} & \multicolumn{2}{|c|}{ Case 2} & \multicolumn{2}{|c|}{ Case 3} & \multicolumn{2}{|c|}{ Case 4} \\
\hline & (ha) & $(\%)$ & (ha) & (\%) & (ha) & $(\%)$ & (ha) & (\%) & (ha) & $(\%)$ \\
\hline $\begin{array}{l}\text { Small-scale } \\
\text { cropland }\end{array}$ & 7716.64 & 4.54 & 2888.32 & 7.70 & 1046.81 & 2.18 & 3644.09 & 6.78 & 137.42 & 0.45 \\
\hline Forest & -14318.40 & -8.43 & -4640.65 & -12.37 & -3719.57 & -7.75 & -4661.85 & -8.68 & -1296.34 & -4.22 \\
\hline Built-up & 298.41 & 0.18 & 6.14 & 0.02 & 28.75 & 0.06 & 11.82 & 0.02 & 251.71 & 0.82 \\
\hline Bare & 414.20 & 0.24 & 29.38 & 0.08 & 316.86 & 0.66 & 17.77 & 0.03 & 50.19 & 0.24 \\
\hline $\begin{array}{l}\text { Cultivated } \\
\text { wetlands }\end{array}$ & -343.12 & -0.20 & 9.16 & 0.02 & -239.23 & -0.50 & 253.96 & 0.47 & -367.01 & -1.20 \\
\hline $\begin{array}{l}\text { Natural } \\
\text { wetlands }\end{array}$ & -559.69 & -0.33 & -522.43 & -1.39 & -4.07 & -0.01 & 81.43 & 0.15 & -114.62 & -0.37 \\
\hline Tea (LAI) & -113.42 & -0.07 & -- & -- & -- & -- & -113.42 & -0.21 & -- & - \\
\hline Soya (LAI) & 4747.06 & 2.79 & 2190.34 & 5.84 & 2320.85 & 4.83 & -- & -- & 235.88 & 0.77 \\
\hline $\begin{array}{l}\text { Macadamia } \\
\text { (LAI) }\end{array}$ & 770.61 & 0.45 & -- & -- & -- & -- & 770.61 & 1.43 & -- & -- \\
\hline $\begin{array}{l}\text { Mech. irrig. } \\
\text { agri. (LAI) }\end{array}$ & 178.32 & 0.10 & -- & -- & -- & -- & 178.32 & 0.33 & -- & -- \\
\hline Sisal (LAI) & -433.21 & -0.25 & -- & -- & -- & -- & -- & -- & -433.21 & -1.41 \\
\hline Cashew & -9.01 & -0.01 & -- & -- & -- & -- & -- & -- & -9.01 & -0.03 \\
\hline Banana (LAI) & 1437.38 & 0.85 & -- & -- & -- & -- & -- & -- & 1437.38 & 4.68 \\
\hline
\end{tabular}

Mech. irrig. agri. = Mechanically irrigated agriculture (pivot irrigation) 
Table 5: Land use changes to LAI and to small-scale cropland as percentage of the new cropland area.

\begin{tabular}{|c|c|c|c|c|c|}
\hline & Overall & Case 1 & $\overline{\text { Case } 2}$ & Case 3 & Case 4 \\
\hline Land use change to & (LAI area: & (LAI area: & (LAI area: & (LAI area: & (LAI area: \\
\hline LAI & 7,166 ha) & 2,190 ha) & 2,321 ha) & 949 ha) & 1,706 ha) \\
\hline Forest to LAI & $39 \%$ & $76 \%$ & $11 \%$ & $67 \%$ & $14 \%$ \\
\hline SSC to LAI & $55 \%$ & $14 \%$ & $85 \%$ & $29 \%$ & $80 \%$ \\
\hline Other to LAI & $6 \%$ & $11 \%$ & $4 \%$ & $4 \%$ & $6 \%$ \\
\hline $\begin{array}{l}\text { Land use change to } \\
\text { small-scale cropland }\end{array}$ & $\begin{array}{c}\text { (New SSC } \\
\text { area: } 21,084)\end{array}$ & $\begin{array}{c}\text { (New SSC } \\
\text { area: } 4,941 \text { ha) }\end{array}$ & $\begin{array}{c}\text { (New SSC area: } \\
5,972 \text { ha) }\end{array}$ & $\begin{array}{c}\text { (New SSC area: } \\
5,611 \text { ha) }\end{array}$ & $\begin{array}{c}\text { (New SSC area: } \\
4,560 \text { ha) }\end{array}$ \\
\hline Forest to SSC & $91 \%$ & $97 \%$ & $96 \%$ & $94 \%$ & $73 \%$ \\
\hline Other to SSC & $9 \%$ & $3 \%$ & $4 \%$ & $6 \%$ & $27 \%$ \\
\hline
\end{tabular}

SSC $=$ small-scale cropland 

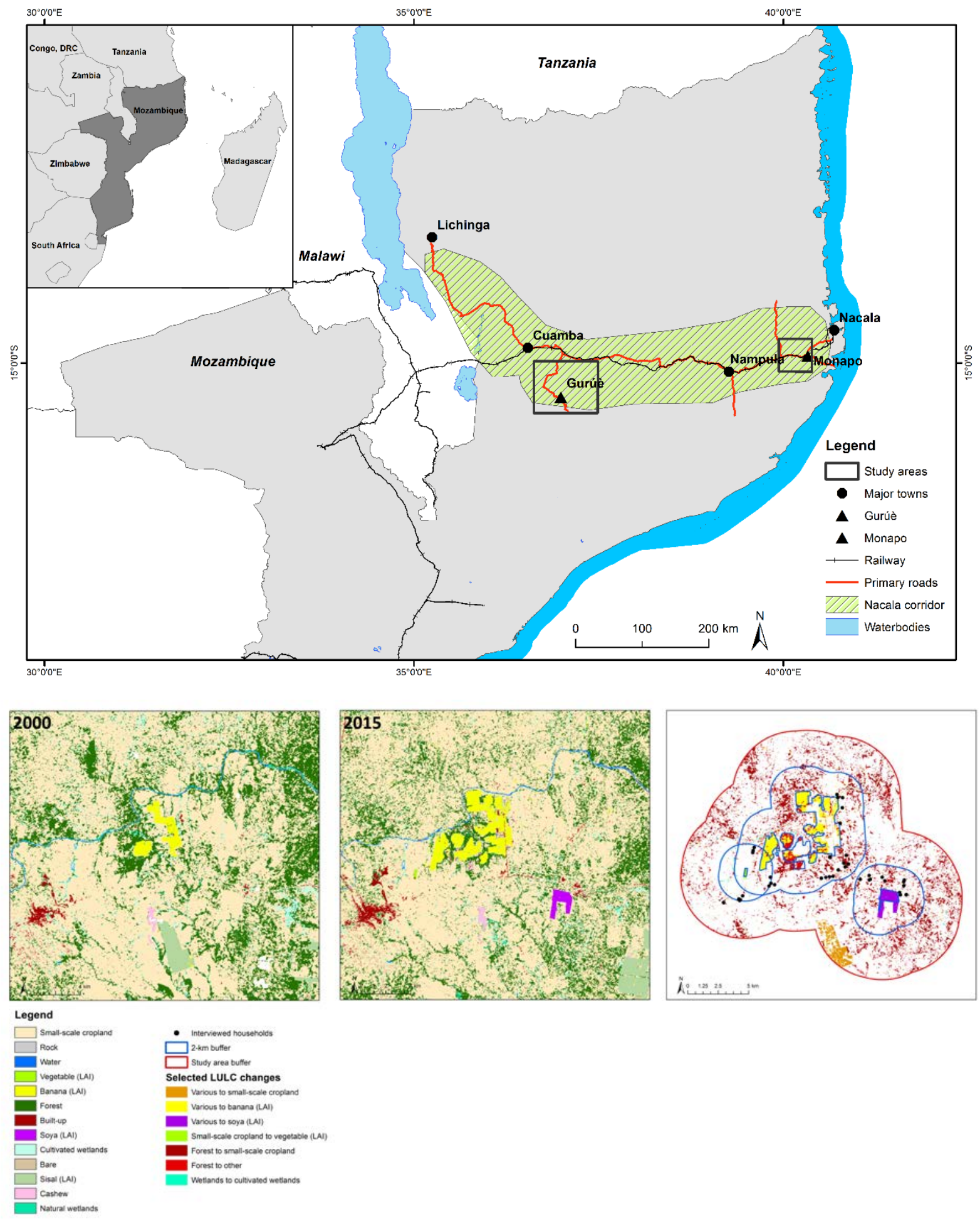

Figure 1: Overview of the Nacala corridor and location of the study areas. 
(a)

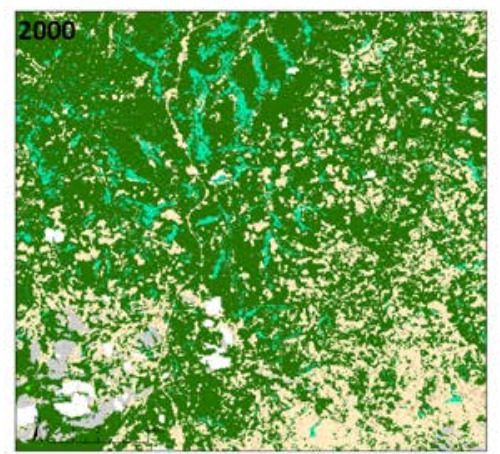

(b)

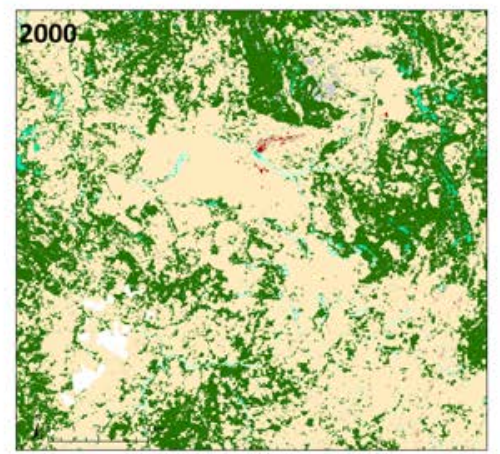

(c)

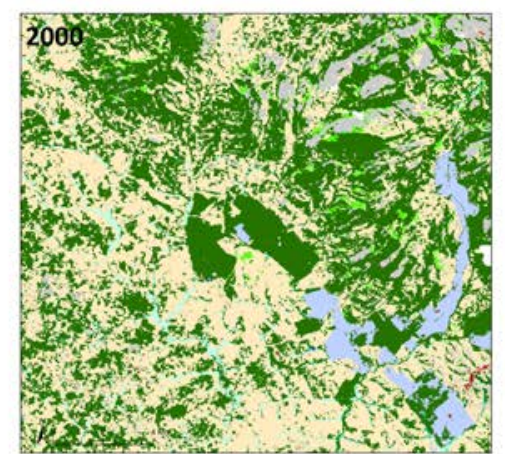

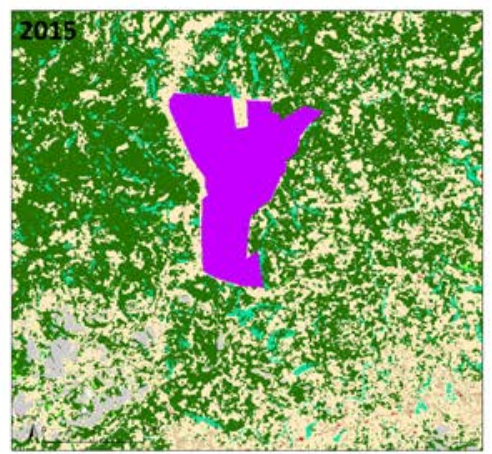
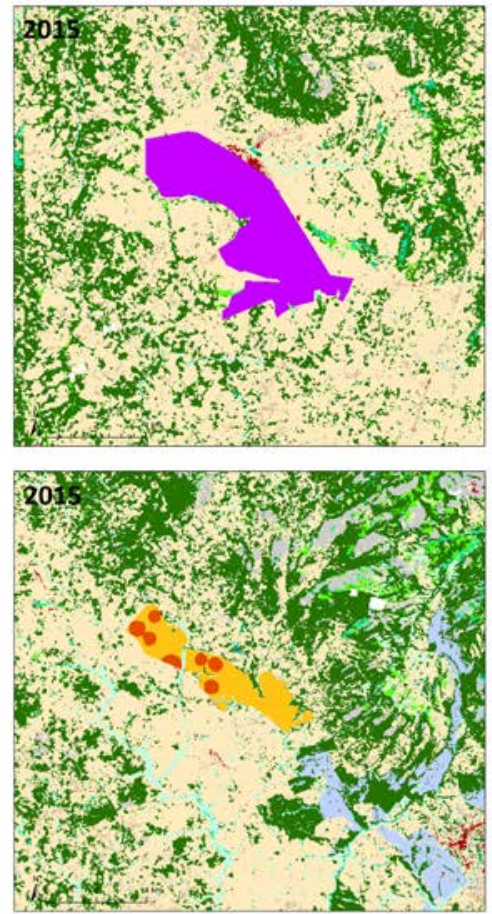
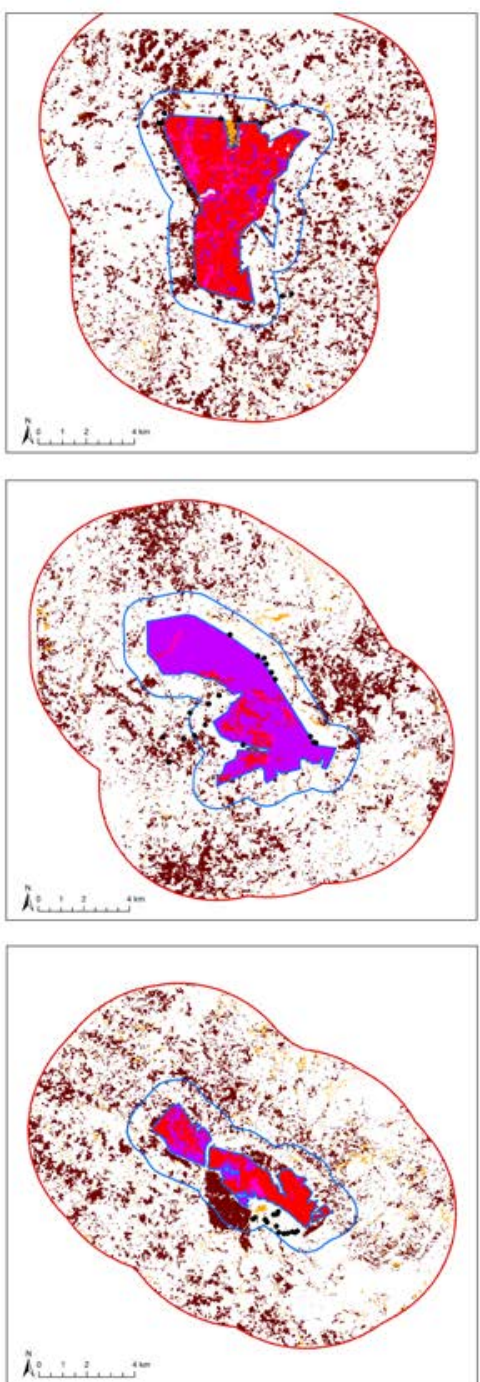

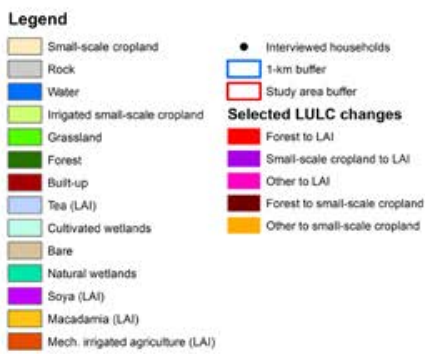

Figure 2: LULC classification maps and change maps of the Guruè study area. The three investigated LAIs are illustrated separately, with (a) showing LAI1, (b) LAI2, and (c) LAI3. The change maps indicate only the most important class changes. 

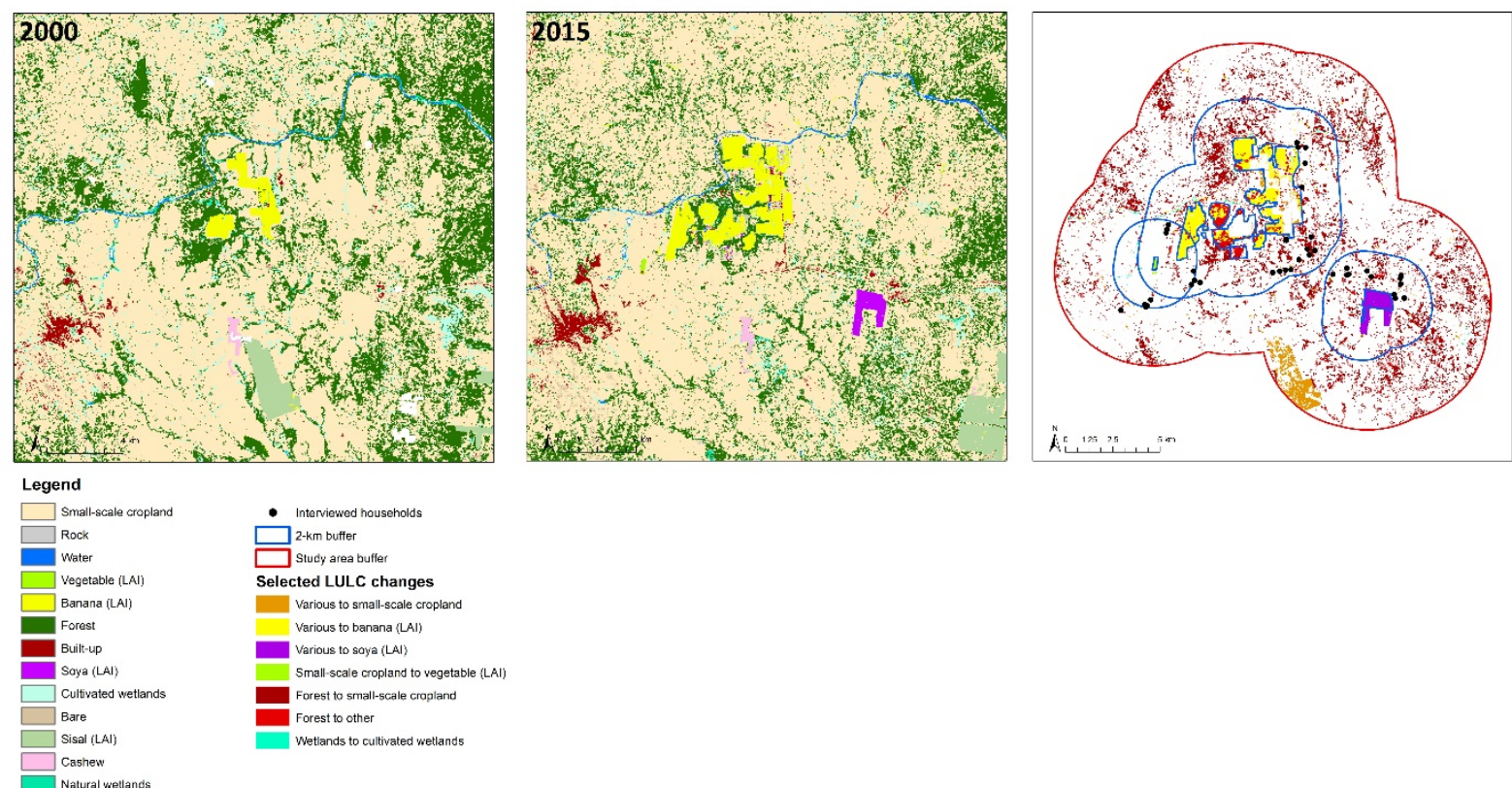

Figure 3: LULC classification maps and change map of the Monapo study area. The change map indicates only the most important class changes.

(a)

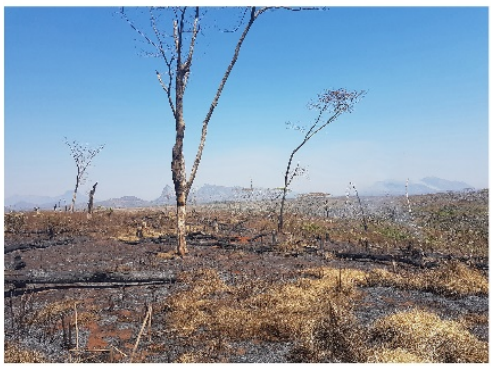

(b)

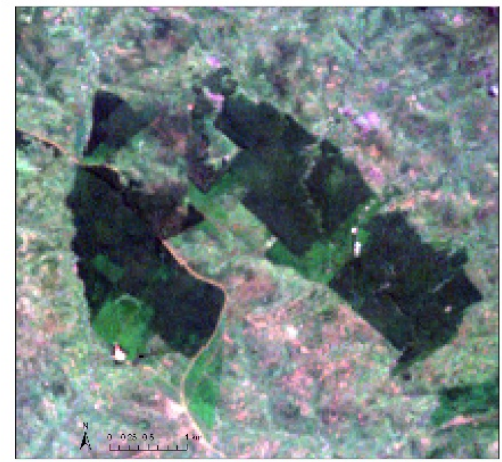

(c)

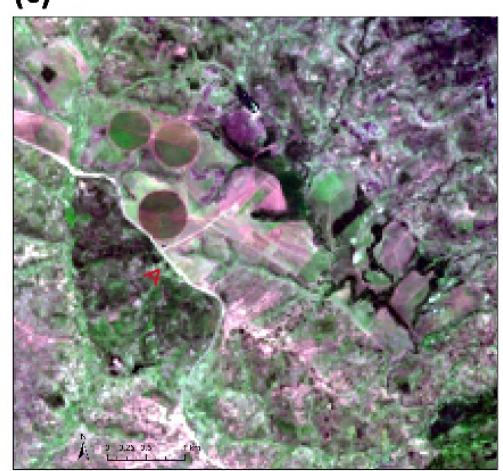

Figure 4: Indirect land use change due to the displacement of small-scale farmers' cropland into forest triggered by the establishment of LAI3, illustrated by (a) a photo taken in September 2016 (by first author) and an excerpt from the Landsat scenes for (b) 2000 and (c) 2015.
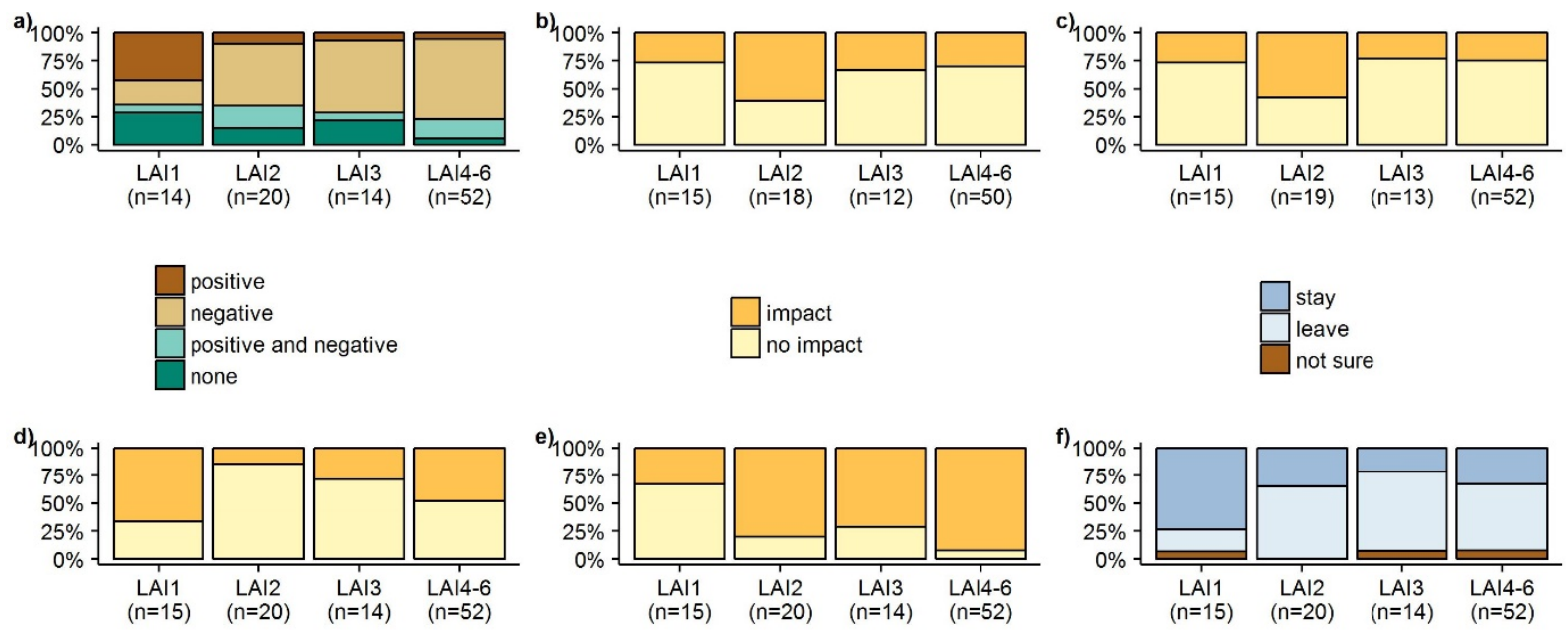

Figure 5. Perceived direct impacts of LAIs on (a) households, (b) the environment, (c) people's health, (d) infrastructure, and (e) conflicts, as well as (f) overall preference of households for 
LAI companies to remain or leave; all expressed as percentages of households reporting impacts or no impacts (a-e) or a certain preference (f). 